medRxiv preprint doi: https://doi.org/10.1101/2021.05.28.21257946; this version posted May 31, 2021. The copyright holder for this preprint (which was not certified by peer review) is the author/funder, who has granted medRxiv a license to display the preprint in perpetuity.

It is made available under a CC-BY-NC-ND 4.0 International license .

\title{
COVID-19 vaccine uptake in United States counties: geospatial vaccination patterns and trajectories towards herd immunity
}

\author{
Pavel Chernyavskiy ${ }^{1}$, Jeanita W. Richardson ${ }^{1}$, Sarah J. Ratcliffe $^{1}$ \\ ${ }^{1}$ : Department of Public Health Sciences, University of Virginia School of Medicine
}

\begin{abstract}
Following the COVID-19 pandemic, safe and effective vaccines were developed and authorized for use in the general population. Studying factors that encourage community acceptance of these vaccines is needed to prevent proliferation of SARS-CoV-2 variants, to safely relax local restrictions, and to return to pre-pandemic living conditions. To our knowledge, United States (US) county-level disparities in vaccination are yet to be investigated. Our data span February May 2021 across 3138 US counties. We consider percentage of residents with at least one dose of an authorized COVID vaccine as the outcome. Spatio-temporal models were used to determine associations of vaccination rates with time-fixed and time-varying covariates. Spatial variability was modelled via Conditional Auto-regressive models; county trajectories over time were specified using random slopes. Greater vaccination rates occur in counties with older residents, high educational attainment, and high proportion of minority residents. Vaccination rates change with COVID risk metrics, suggesting continued slowing of vaccine uptake due to decreasing incidence and infection rates. County effects reveal strong regional patterns in average vaccination rates and trajectories. Although local herd immunity can be expected in August 2021 for counties with typical uptake rates, these counties are clustered in relatively few areas of the country.
\end{abstract}


medRxiv preprint doi: https://doi.org/10.1101/2021.05.28.21257946; this version posted May 31, 2021. The copyright holder for this preprint (which was not certified by peer review) is the author/funder, who has granted medRxiv a license to display the preprint in perpetuity.

It is made available under a CC-BY-NC-ND 4.0 International license .

\section{INTRODUCTION}

The Coronavirus Disease (COVID)-19 pandemic has been a defining generational event, with no country, region, or municipality spared. Following the rapid development of several safe and effective vaccines ${ }^{1-3}$, encouraging broad community acceptance has become crucially important ${ }^{4,5}$. Although some progress towards population herd immunity is expected by summer of $2021^{6}$, it is yet unclear how the increasing prevalence of novel SARS-CoV-2 variants ${ }^{7}$, the incidence of break-through infections ${ }^{8}$, and levels of vaccine hesitancy will affect this timeline ${ }^{9-}$ 11 .

Early research around COVID vaccine acceptance has been prospective, with many findings based on surveys about a potential vaccine ${ }^{12-15}$, and/or limited to a population of healthcare workers ${ }^{16,17}$. Recent work has targeted the general population to investigate associations between demographics and attitudes towards the vaccine. Evidence from the United Kingdom (UK) suggests that vaccine hesitancy is higher among younger, lower income, lower education, and non-White minority ethnic groups ${ }^{18}$. The same survey also suggested associations with perceived risk from COVID, reliance on information obtained via specific social media platforms, and levels of trust in government and public health officials. Latent psychological factors, such as religiosity, social dominance, cognitive reflection, and altruism have also been associated with COVID vaccine attitudes in the UK and Ireland ${ }^{19}$.

Besides population characteristics, there is strong evidence that political ideology influences vaccine attitudes. Survey responses from France indicate that the odds of acceptance were highest when respondents identified with the governing party ${ }^{20}$. Recent polls ${ }^{21,22}$ from the US also found stark differences by political affiliation: Democrats - the current governing party - as well as individuals who identified as "liberal" reported being more accepting than Republicans and individuals who identified as "conservative". However, differences by 
medRxiv preprint doi: https://doi.org/10.1101/2021.05.28.21257946; this version posted May 31, 2021. The copyright holder for this preprint (which was not certified by peer review) is the author/funder, who has granted medRxiv a license to display the preprint in perpetuity. It is made available under a CC-BY-NC-ND 4.0 International license .

race/ethnicity (White vs. Black) were comparatively small relative to differences by political ideology and data on racial/ethnic differences from the $\mathrm{UK}^{23}$. The extent of racial/ethnic disparities in the US is yet unknown because demographics are available for only $55 \%$ of Americans who have received at least one dose. The majority of this group is comprised of White (64\%) individuals, followed by Hispanic (12\%), Black (9\%), and Asian $(5 \%)^{24}$. Further, documented experimentation at the hands of researchers in communities of color could fuel vaccine hesitancy in the $\mathrm{US}^{25}$.

The recent US poll ${ }^{21}$ found that political affiliation is additionally responsible for the variable levels of trust in health experts, broadcast news media, and elected officials with respect to vaccine information. The lack of consensus around credible sources has fueled misinformation around the vaccine, including false claims that vaccines: are linked to cellular networks, are a vehicle to implant microchips, are able to modify the human genome, or that the development process was rushed ${ }^{26}$. In the case of Janssen (Johnson \& Johnson), religiosity may influence vaccine uptake given its designation as "morally compromised",27. Not surprisingly, exposure to misinformation is harmful to acceptance: an experiment conducted on UK and US participants showed that misinformation reduced intent to get vaccinated; however, women, ethnic minorities, and low-income participants exhibited greater resistance ${ }^{28}$. Additionally, misinformation contributes to fear around vaccination, which in-turn reduces willingness to be vaccinated $^{22}$.

Although US vaccination figures are available through several reliable sources (e.g., $\mathrm{CDC}^{29}$, Johns Hopkins Coronavirus Resource $\mathrm{Center}^{30}$ ), there has been a dearth of studies at the sub-state level. Here, we focus on disparities in vaccination rates among US counties. We investigate geographic disparities in average vaccination rates, as well as disparities in the trends 
medRxiv preprint doi: https://doi.org/10.1101/2021.05.28.21257946; this version posted May 31, 2021. The copyright holder for this preprint (which was not certified by peer review) is the author/funder, who has granted medRxiv a license to display the preprint in perpetuity. It is made available under a CC-BY-NC-ND 4.0 International license .

of uptake over time, which we call vaccination trajectories. We partition geographic disparities into "expected", which are attributable to socio-demographic and disease risk factors (e.g., age, educational attainment, COVID incidence rates), and "latent", which are a function of unobserved or unobservable factors (e.g., political affiliation, levels of trust in officials). In doing so, we identify counties that are over- and under-performing based on their known population characteristics. The estimated vaccination trajectories are then used to forecast when vaccination rates for representative counties are expected to reach a herd immunity threshold of $70 \%$. Consensus around herd immunity for COVID has not yet been established; however, the threshold used in this article is among the plausible levels cited by the Mayo Clinic ${ }^{31}$ and the Kaiser Foundation $^{32}$. Finally, we demonstrate that our predictive model is accurate up to an 8 week-ahead forecast, making our predictions useful for modifying within-state vaccine distribution, adjusting vaccination centers' staffing needs, and informing investments in local interventions.

\section{METHODS}

\section{Data sources}

Vaccination data were downloaded from the COVID Act Now Application Programming Interface $^{33}$, using an access key obtained in January 2021. COVID Act Now is a nonprofit organization that aggregates data reported by the US Department of Health and Human Services, CDC, and online dashboards for individual states and counties. Data were available for all 50 US states and the District of Columbia, which comprised 3138 (99.9\%) counties covering 98.7\% of the 2018 US population. Daily vaccinations for each county were aggregated into calendar weeks to avoid day-of-week effects and to reduce noise due to reporting delays and data revisions that may take place within the week. Because county-level data for all 50 states became available only on May 1 , our data span the most recent 13 weeks from February $21^{\text {st }}$ through May $16^{\text {th }}$. 
medRxiv preprint doi: https://doi.org/10.1101/2021.05.28.21257946; this version posted May 31, 2021. The copyright holder for this preprint (which was not certified by peer review) is the author/funder, who has granted medRxiv a license to display the preprint in perpetuity. It is made available under a CC-BY-NC-ND 4.0 International license .

Growing evidence points to significant protection from SARS-CoV-2 after one of two planned doses of Pfizer-BioNTech and Moderna ${ }^{34}$, and one planned dose of Janssen. Thus, our outcome variable, was the percentage of county residents with at least 1 dose of these three vaccines, which have emergency use authorization from the US Food and Drug Administration at the time of writing.

\section{County covariates}

Time-invariant demographics were obtained from the 2015 American Community Survey accessed via the choroplethr $\mathrm{R}$ package ${ }^{35}$, which included percentages of Hispanic, Black, and Asian residents, and the US Department of Agriculture 2015 Rural Atlas ${ }^{36}$, which included population density, percentages of residents with at most a high school diploma and with at least a 4-year college degree, as well as percentage of Native American residents. Percentage of county residents under age 18 and over age 65 in 2018 was obtained from the CDC Social Vulnerability Index (SVI) webpage ${ }^{37}$, which also contains the estimated 2018 county population, and county polygon boundaries and percentile rankings for the four SVI themes: Socioeconomic Status, Household Composition and Disability, Minority Status and Language, and Housing Type and Transportation. The CDC SVI reflects the socioeconomic conditions of each county and is constructed using 15 county variables, which are current as of 2018. Data were merged using the unique county FIPS code.

Time-varying metrics on COVID incidence rates per 100,000 residents, estimated infection rates $\left(\mathrm{R}_{\mathrm{t}}\right)$, and test positivity rates, were obtained from the COVID Act Now API and aggregated into calendar weeks to match the temporal scale of analysis. Mortality rates were available but were excluded due to high correlation with incidence rates.

\section{Statistical analysis}


medRxiv preprint doi: https://doi.org/10.1101/2021.05.28.21257946; this version posted May 31, 2021. The copyright holder for this preprint (which was not certified by peer review) is the author/funder, who has granted medRxiv a license to display the preprint in perpetuity. It is made available under a CC-BY-NC-ND 4.0 International license .

We used approximate Bayesian models, implemented via Integrated Nested Laplace Approximation (INLA) $)^{38}$ in $\mathrm{R} 4.0^{39}$ for all estimation. INLA is a popular computing platform in public health for data collected across non-overlapping discrete regions ${ }^{40-43}$. Our models fall within Latent Gaussian Models - the broad class of models for which INLA was developed. Our outcome variable, $Y_{c t}$, is defined as the proportion of residents for each county $c\left(c=1, \ldots, N_{c}\right)$ at the end of week $t\left(t=1, \ldots, N_{t}\right)$ with at least one dose of the COVID vaccine. A Beta regression framework ${ }^{44}$ was employed, such that $Y_{c t} \sim \operatorname{Beta}\left(\mu_{c t}, \phi\right)$ with a space-time-varying mean $^{45,46}$ denoted by $\mu_{c t}$ :

$$
g\left(\mu_{c t}\right)=\beta_{0}+x_{c}^{\prime} \beta+\xi_{c}+u_{c}+z_{c t}^{\prime} \gamma+\left(v_{c}+\beta_{t}\right) w e e k_{t}+\delta_{c t}
$$

where $g(\quad)$ is the probit link function and $\phi$ is the Beta regression scale parameter.

In equation (1), $\beta$ are the coefficients of time-fixed covariates, and $\gamma$ are the coefficients of time-varying covariates. Spatially structured and unstructured latent county effects are captured by $\xi_{c}$ and $u_{c}$, respectively. The former is specified using correlation structures from the Conditionally Autoregressive $(\mathrm{CAR})^{47}$ class with the county adjacency matrix as an input; the latter is specified as an exchangeable random intercept. Jointly, these latent effects measure how vaccination rates vary around the expected value under the model; their sum measures whether each county is over-performing $\left(\xi_{c}+u_{c}>0\right)$, or under-performing $\left(\xi_{c}+u_{c}<0\right)$ expectations based on known characteristics.

The coefficient $\beta_{t}$ measures the trend in vaccination rates over time - the shape of the vaccination trajectory - for the typical county. Random "slopes" $v_{c}$ modify $\beta_{t}$ such that each county is allowed its own trajectory $\left(v_{c}+\beta_{t}\right)$. Counties where $v_{c}>0$ have more favorable (i.e., steeper) trajectories than the typical county and vice-versa. The term $\delta_{c t}$ captures space-time (county-week) variability in mean vaccination rates and is specified as a random intercept. 
medRxiv preprint doi: https://doi.org/10.1101/2021.05.28.21257946; this version posted May 31, 2021. The copyright holder for this preprint (which was not certified by peer review) is the author/funder, who has granted medRxiv a license to display the preprint in perpetuity.

It is made available under a CC-BY-NC-ND 4.0 International license .

We computed observed and forecasted trajectories for representative counties that fall into different percentiles of the trajectory distribution: top $10 \%$, top $25 \%$, median, bottom $25 \%$, and bottom 10\%. Each percentile threshold captures several counties; we selected a representative county such that the posterior $\mathrm{SD}$ of its random slope $\left(v_{c}\right)$ is smallest. Once the representative county is selected $\left(c=c^{*}\right)$, we construct its trajectory using its latent parameter estimates for $\xi_{c^{*}}, u_{c^{*}}, v_{c^{*}}$, global fixed effects $\beta_{0}$ and $\beta_{t}$, assuming all other covariates are held at their average values and averaging over $\delta_{c t}$.

We evaluated several space-time models and selected one using well-established metrics: WAIC and the logarithmic score (LS). We provide more details of our statistical modeling in Supplementary Materials, including: an overview of INLA estimation, prior distributions used, and results from a predictive cross-validation exercise with up to an 8-week-ahead forecast. Diagnostics and parameter estimates for the selected model are shown as part of Supplementary Materials. Additionally, we provide an interactive version of all maps in this article at the following publicly accessible repository (https://github.com/pchernya/Covid Vaccine US) that will be updated each week, along with our projections, as new data become available.

\section{RESULTS}

Data from more counties became available over time (Figure 1; Supplementary Table 4); our final counties $\times$ weeks sample size was 33055 . County covariates were generally uncorrelated: the largest correlations were between percentages of residents under age 18 and over age 65 $(\rho=-0.58)$ and percentages of residents with at most a high school diploma and at least a college degree $(\rho=-0.61)$ (Supplementary Figure 1); these covariates remained in the statistical model together.

\section{Time-invariant and time-varying coefficients}


medRxiv preprint doi: https://doi.org/10.1101/2021.05.28.21257946; this version posted May 31, 2021. The copyright holder for this preprint (which was not certified by peer review) is the author/funder, who has granted medRxiv a license to display the preprint in perpetuity. It is made available under a CC-BY-NC-ND 4.0 International license .

Counties with high vaccination rates tended to be older, college-educated communities, with high proportions of minority residents, especially Hispanic and Native American individuals (Figure 2). Alternatively, counties with low vaccination rates tended to have low educational attainment and high proportions of children under age 18. Among the time-varying metrics, counties with higher COVID incidence and higher infection rates tended to have higher vaccination rates, whereas counties with high test positivity rates tended to have lower rates.

\section{Latent county effects}

Latent county effects and vaccination trajectories reveal strong regional patterns. The majority of counties in New England, Middle Atlantic, and East-North Central US are over-performing, or performing in-line with their known characteristics (Figure 3A). With the exception of Arkansas, Oklahoma, and South Carolina, counties in South Atlantic, East, and West South Central are under-performing their characteristics. Evidence from western US is mixed: counties in California, Kansas, New Mexico, and Utah are largely over-performing, counties in Arizona, Colorado, Nevada, and Wyoming are largely underperforming, and the remaining states have mixed localized patterns. For example, Nebraska, North Dakota, and South Dakota have strong East-West gradients where counties in the East are over-performing expectations and vice-versa.

Among the 10 most over-performing counties, 7 are sparsely populated communities in Alaska and North Dakota, and the remaining 3 are in Iowa, New Hampshire, and Virginia (Table 1). The CDC SVI suggests that communities in Alaska face challenges related to housing and transportation and minority and language status. Both counties in North Dakota have favorable rankings across the four SVI themes. The county in Virginia stands out due to its minority and language status, whereas the county in New Hampshire stands out due to its household composition and disability status, as well as its housing and transportation status. 
medRxiv preprint doi: https://doi.org/10.1101/2021.05.28.21257946; this version posted May 31, 2021. The copyright holder for this preprint (which was not certified by peer review) is the author/funder, who has granted medRxiv a license to display the preprint in perpetuity. It is made available under a CC-BY-NC-ND 4.0 International license .

Vaccination trajectories tended to be more favorable in New England, Middle Atlantic, along the Pacific coast, and also in the majority of Florida, Hawaii, Michigan, Minnesota, and New Mexico (Figure 3B). Counties that cover populous metropolitan areas have more favorable trajectories than the surrounding counties, for example: Atlanta, GA; Austin, TX; Chicago, IL; Columbus, OH; Dallas, TX; Denver, CO; Houston, TX; Nashville, TN; and, St. Louis, MO.

Except for counties in Alaska, Nevada, and New Mexico, the 10 most favorable trajectories are generally in the Northeast (Table 2). These counties tend to have favorable socioeconomic status, household composition and disability rankings, as well as housing and transportation rankings, with notable exceptions in Alaska and Vermont. Manassas Park City in Virginia stands out because it is also the most over-performing county in Table 1.

\section{Forecasted trajectories}

To illustrate the implications of the disparity in vaccination trajectories, we forecasted vaccination rates for counties in the top $10 \%$, top $25 \%$, median, bottom $25 \%$, and bottom $10 \%$ of the estimated trajectories distribution (Figure 4). Using $70 \%$ as the herd immunity threshold, counties in the top $10 \%$ and top $25 \%$ are forecasted to reach herd immunity by the week of June 13-19 (Figure 4B I) and July 25-31 (Figure 4B II), respectively. Counties with median trajectories are expected to reach herd immunity by August 8-14 (Figure 4B III), but counties in the bottom $25 \%$ of estimated trajectories are only expected to clear the $40 \%$ threshold at that time. If current trends hold, these bottom- $25 \%$ counties are not expected to reach herd immunity until the last week of 2021 (Figure 4B IV), whereas counties in the bottom $10 \%$ take until later in 2022.

The forecast for the end of July 2021 (Figure 5A) shows that modal vaccination rates are expected to be between $40 \%$ and $60 \%$, with some areas as low as $20 \%$. The herd immunity 
medRxiv preprint doi: https://doi.org/10.1101/2021.05.28.21257946; this version posted May 31, 2021. The copyright holder for this preprint (which was not certified by peer review) is the author/funder, who has granted medRxiv a license to display the preprint in perpetuity. It is made available under a CC-BY-NC-ND 4.0 International license .

forecast (Figure 5B) indicates that local immunity can be expected for: most of the counties in the Northeast, coastal Pacific counties, coastal Florida counties, the majority of southern border counties in Texas and New Mexico, and the majority of Hawaii. Additionally, urban areas of Colorado, Illinois, Indiana, Michigan, Minnesota, Ohio, Tennessee, and Texas are also expected to attain local herd immunity.

Our model was accurate for 1-, 2-, and 4-week ahead forecasts, with mean absolute predictive errors of $3.82 \%, 5.98 \%$, and $9.45 \%$ and predictive Pearson correlations of $0.98,0.97$, and 0.95 , respectively (Supplementary Table 2; Supplementary Figure 2). Forecast accuracy deteriorated for the 8-week ahead forecast, with mean absolute predictive error of $16.05 \%$ and predictive Pearson correlation of 0.64 .

\section{DISCUSSION}

To our knowledge, our article describes the first predictive spatio-temporal analysis of US county COVID vaccination uptake. We identified demographic factors and disease risk metrics that explain variability in county vaccination rates and determined counties that over- and underperform their demographics due to unobserved local factors. Geographic disparities in average vaccination rates and vaccination trajectories were stark, with the latter revealing localized favorable trends concentrated in metropolitan areas. Our forecasts show a growing divide between high-uptake and low-uptake counties: those in the top $25 \%$ of estimated vaccination trajectories are expected to reach a $70 \%$ herd immunity threshold by the end of July 2021 , but those in bottom $25 \%$ only by the first week of 2022 . Although the median trajectory counties are expected to reach herd immunity by the start of the Fall 2021 school year, these counties are generally concentrated in only a few areas of the country and so the next school year may be adversely affected across a large portion of the US. 
medRxiv preprint doi: https://doi.org/10.1101/2021.05.28.21257946; this version posted May 31, 2021. The copyright holder for this preprint (which was not certified by peer review) is the author/funder, who has granted medRxiv a license to display the preprint in perpetuity. It is made available under a CC-BY-NC-ND 4.0 International license .

Intuitively and in-line with UK data ${ }^{18}$, we show that older and more educated communities have had higher vaccine uptake to date, whereas younger and less educated communities have had lower uptake. This is not surprising given that vaccinations first available to older adults and the use of online sign-up systems are barriers to low-income and communities of color ${ }^{48,49}$. Additionally, county vaccination rates change with COVID risk levels in the community as counties with higher incidence and infection rates have higher vaccination rates, on average. This suggests that greater visibility of current community risk via local media channels may be beneficial.

Less intuitively, we offer evidence that counties with large minority populations, especially Hispanic, Native, and Black residents, have higher vaccination uptake. This result might be attributed to health officials' efforts to reach minority populations early with targeted messaging ${ }^{50}$ plus the fact that minorities have had a disproportionate number of cases and deaths during the pandemic. Consistent with greater vaccination rates among residents who perceive greater risk ${ }^{19}$, minority communities may be more accepting of the COVID vaccine than suggested by prior surveys ${ }^{21}$.

Our finding of negative association between test positivity and vaccination rates may also be unintuitive. In our view, this variable acts as a proxy for testing behavior as opposed to a measure of community risk. Counties with high test positivity may signal that it is difficult to obtain a test, or residents tend to get tested only after symptoms have developed. This may also reflect the perception that a positive test indicates one will become immune after several weeks and so residents are less likely to obtain a vaccination.

Our ability to score each county as over- or under-performing their known characteristics can inform vaccine redistribution efforts within- and between-states. Our models were accurate 
medRxiv preprint doi: https://doi.org/10.1101/2021.05.28.21257946; this version posted May 31, 2021. The copyright holder for this preprint (which was not certified by peer review) is the author/funder, who has granted medRxiv a license to display the preprint in perpetuity. It is made available under a CC-BY-NC-ND 4.0 International license .

within a 4-weeks-ahead forecast and may still be useful up to an 8-week-ahead forecast. Predicted vaccination rates will be updated on a weekly basis on this website (https://github.com/pchernya/Covid Vaccine US). In addition to vaccine redistribution, these can inform local reopening policies, and staffing levels at vaccination sites.

Our article has several important limitations. First, our data are ecological in nature, only available at the level of county. Thus, we cannot use our analysis to infer behavior for any individual resident. Second, while the CDC reports making reasonable efforts to determine county of residence, certain reporting practices, such as reporting through retail pharmacies, federal facilities, or long-term care facilities may result in low vaccination coverage data. This has potential to add noise to our vaccination maps, especially in areas of high resident mobility or vaccination tourism. Third, although we produce accurate short-term forecasts, unforeseen factors such as discoveries of major adverse reactions, geopolitical events, natural disasters, and logistical breaks in the supply chain cannot be incorporated into our forecast, although these will certainly affect vaccination uptake. In fact, our longer-term forecast should only be considered as a counter-factual scenario if current trends hold. 
medRxiv preprint doi: https://doi.org/10.1101/2021.05.28.21257946; this version posted May 31, 2021. The copyright holder for this preprint

(which was not certified by peer review) is the author/funder, who has granted medRxiv a license to display the preprint in perpetuity. It is made available under a CC-BY-NC-ND 4.0 International license .

\section{References}

1. Polack, F. P., Thomas, S. J., Kitchin, N., Absalon, J., Gurtman, A., Lockhart, S., ... \& Gruber, W. C. (2020). Safety and efficacy of the BNT162b2 mRNA Covid-19 vaccine. New England Journal of Medicine, 383(27), 2603-2615.

2. Baden LR, El Sahly HM, Essink B, Kotloff K, Frey S, Novak R, Diemert D, Spector SA, Rouphael N, Creech CB, McGettigan J. Efficacy and safety of the mRNA-1273 SARS-CoV2 vaccine. New England Journal of Medicine. 2021 Feb 4;384(5):403-16.

3. Mahase E. Covid-19: Where are we on vaccines and variants? BMJ 2021; 372 :n597 doi:10.1136/bmj.n597

4. M Mello MM, Silverman RD, Omer SB. Ensuring uptake of vaccines against SARS-CoV-2. New England Journal of Medicine. 2020 Oct 1;383(14):1296-9.

5. Moore, S., Hill, E. M., Tildesley, M. J., Dyson, L., \& Keeling, M. J. (2021). Vaccination and non-pharmaceutical interventions for COVID-19: a mathematical modelling study. The Lancet Infectious Diseases. 2021 Mar 18.

6. Is herd immunity closer than we think? [Internet]. Aamc.org. [accessed 2021 May 14]. Available from: https://www.aamc.org/news-insights/herd-immunity-closer-we-think

7. Hacisuleyman E, Hale C, Saito Y, Blachere NE, Bergh M, Conlon EG, Schaefer-Babajew DJ, DaSilva J, Muecksch F, Gaebler C, Lifton R. Vaccine Breakthrough Infections with SARS-CoV-2 Variants. New England Journal of Medicine. 2021 Apr 21. doi: 10.1056/NEJMoa2105000.

8. Rubin R. COVID-19 Vaccines vs Variants-Determining How Much Immunity Is Enough. JAMA. 2021;325(13):1241-1243. doi:10.1001/jama.2021.3370

9. Peretti-Watel P, Seror V, Cortaredona S, Launay O, Raude J, Verger P, Fressard L, Beck F, Legleye S, l'Haridon O, Léger D. A future vaccination campaign against COVID-19 at risk of vaccine hesitancy and politicisation. The Lancet Infectious Diseases. $2020 \mathrm{Jul}$ 1;20(7):769-70.

10. Fridman A, Gershon R, Gneezy A (2021) COVID-19 and vaccine hesitancy: A longitudinal study. PLoS ONE 16(4): e0250123. doi:10.1371/journal.pone.0250123

11. McCabe SD, Hammershaimb EA, Cheng D, Shi A, Shyr D, Shen S, Cole LD, Cataldi JR, Allen W, Probasco R, Silbermann B, Zhang F, Marsh R, Travassos MA, Lin X. Unraveling Attributes of COVID-19 Vaccine Hesitancy in the U.S.: A Large Nationwide Study. medRxiv [Preprint]. 2021 Apr 7:2021.04.05.21254918. doi: 10.1101/2021.04.05.21254918. PMID: 33851172; PMCID: PMC8043469.

12. Dror AA, Eisenbach N, Taiber S, Morozov NG, Mizrachi M, Zigron A, Srouji S, Sela E. Vaccine hesitancy: the next challenge in the fight against COVID-19. European journal of epidemiology. 2020 Aug;35(8):775-9.

13. Lazarus JV, Ratzan SC, Palayew A, Gostin LO, Larson HJ, Rabin K, Kimball S, ElMohandes A. A global survey of potential acceptance of a COVID-19 vaccine. Nature medicine. 2021 Feb;27(2):225-8.

14. Skjefte, M., Ngirbabul, M., Akeju, O., Escudero, D., Hernandez-Diaz, S., Wyszynski, D. F., $\& \mathrm{Wu}, \mathrm{J}$. W. (2021). COVID-19 vaccine acceptance among pregnant women and mothers of young children: results of a survey in 16 countries. European journal of epidemiology, 36(2), 197-211. 
medRxiv preprint doi: https://doi.org/10.1101/2021.05.28.21257946; this version posted May 31, 2021. The copyright holder for this preprint

(which was not certified by peer review) is the author/funder, who has granted medRxiv a license to display the preprint in perpetuity. It is made available under a CC-BY-NC-ND 4.0 International license .

15. Ward JK, Alleaume C, Peretti-Watel P; COCONEL Group. The French public's attitudes to a future COVID-19 vaccine: The politicization of a public health issue. Soc Sci Med. 2020;265:113414. doi:10.1016/j.socscimed.2020.113414

16. Gadoth, A., Halbrook, M., Martin-Blais, R., Gray, A., Tobin, N. H., Ferbas, K. G., ... \& Rimoin, A. W. (2021). Cross-sectional Assessment of COVID-19 vaccine acceptance among health care workers in Los Angeles. Annals of internal medicine.

17. Kwok KO, Li KK, Wei WI, Tang A, Wong SY, Lee SS. Influenza vaccine uptake, COVID19 vaccination intention and vaccine hesitancy among nurses: A survey. International journal of nursing studies. 2021 Feb 1;114:103854.

18. Allington D, McAndrew S, Moxham-Hall V, Duffy B. Coronavirus conspiracy suspicions, general vaccine attitudes, trust, and coronavirus information source as predictors of vaccine hesitancy among UK residents during the COVID-19 pandemic. Psychological Medicine. 2021 Apr 12:1-7.

19. Murphy, J., Vallières, F., Bentall, R. P., Shevlin, M., McBride, O., Hartman, T. K., ... \& Hyland, P. (2021). Psychological characteristics associated with COVID-19 vaccine hesitancy and resistance in Ireland and the United Kingdom. Nature communications, 12(1), $1-15$.

20. Schwarzinger M, Watson V, Arwidson P, Alla F, Luchini S. COVID-19 vaccine hesitancy in a representative working-age population in France: a survey experiment based on vaccine characteristics. The Lancet Public Health. 2021 Apr 1;6(4):e210-21.

21. SteelFisher, G. K., Blendon, R. J., \& Caporello, H. (2021). An Uncertain PublicEncouraging Acceptance of Covid-19 Vaccines. New England Journal of Medicine.

22. Killgore WD, Cloonan SA, Taylor EC, Dailey NS. The COVID-19 Vaccine Is Here-Now Who Is Willing to Get It?. Vaccines. 2021 Apr;9(4):339.

23. Razai M S, Osama T, McKechnie D G J, Majeed A. Covid-19 vaccine hesitancy among ethnic minority groups BMJ 2021; 372 :n513 doi:10.1136/bmj.n513

24. Ndugga, N., Pham, O., Hill, L., Artiga, S., Alam, R., and Parker, N. Latest Data on COVID19 Vaccinations Race/Ethnicity (April 21, 2021). Accessed on April 25, 2021.

25. Washington HA. Medical Apartheid: The dark history of medical experimentation on Black Americans from colonial time to the present. New York : Doubleday, 2006.

26. Hotez P, Batista C, Ergonul O, Figueroa JP, Gilbert S, Gursel M, Hassanain M, Kang G, Kim JH, Lall B, Larson H. Correcting COVID-19 vaccine misinformation: Lancet Commission on COVID-19 Vaccines and Therapeutics Task Force Members. EClinicalMedicine. 2021 Mar $1 ; 33$.

27. Misick B-J. Catholic leaders voice moral concerns about Johnson \& Johnson vaccine. NPR [Internet]. 2021 Mar 11 [cited 2021 May 23]; Available from: https://www.npr.org/2021/03/11/975964553/catholic-leaders-voice-moral-concerns-aboutjohnson-johnson-vaccine

28. Loomba S, de Figueiredo A, Piatek SJ, de Graaf K, Larson HJ. Measuring the impact of COVID-19 vaccine misinformation on vaccination intent in the UK and USA. Nature human behaviour. 2021 Mar;5(3):337-48.

29. COVID-19 Vaccination | CDC [Internet]. Cdc.gov. 2021 [cited 26 April 2021]. Available from: https://www.cdc.gov/vaccines/covid-19/index.html 
medRxiv preprint doi: https://doi.org/10.1101/2021.05.28.21257946; this version posted May 31, 2021. The copyright holder for this preprint

(which was not certified by peer review) is the author/funder, who has granted medRxiv a license to display the preprint in perpetuity.

It is made available under a CC-BY-NC-ND 4.0 International license .

30. Vaccines - Johns Hopkins Coronavirus Resource Center [Internet]. Johns Hopkins Coronavirus Resource Center. 2021 [cited 26 April 2021]. Available from:

https://coronavirus.jhu.edu/vaccines

31. Herd immunity and COVID-19 (coronavirus): What you need to know [Internet]. Mayo Clinic. 2021 [cited 26 April 2021]. Available from: https://www.mayoclinic.org/diseasesconditions/coronavirus/in-depth/herd-immunity-and-coronavirus/art-20486808

32. Rodriguez C. Can Vaccination and Infection Rates Add Up to Reach Covid Herd Immunity? [Internet]. Kaiser Health News. 2021 [cited 26 April 2021]. Available from:

https://khn.org/news/article/can-vaccination-and-infection-rates-add-up-to-reach-covid-herdimmunity/

33. U.S. COVID Risk \& Vaccine Tracker [Internet]. Covid Act Now. 2021 [cited 26 April 2021]. Available from: https://covidactnow.org/data-api

34. Thompson MG, Burgess JL, Naleway AL, et al. Interim Estimates of Vaccine Effectiveness of BNT162b2 and mRNA-1273 COVID-19 Vaccines in Preventing SARS-CoV-2 Infection Among Health Care Personnel, First Responders, and Other Essential and Frontline Workers — Eight U.S. Locations, December 2020-March 2021. MMWR Morb Mortal Wkly Rep 2021;70:495-500. DOI: http://dx.doi.org/10.15585/mmwr.mm7013e3external

35. Lamstein, A. choroplethr: Simplify the Creation of Choropleth Maps in R. R package version 3.7.0. 2020. Available from: https://CRAN.R-project.org/package=choroplethr

36. USDA ERS - Atlas of Rural and Small-Town America [Internet]. Ers.usda.gov. 2021 [cited 26 April 2021]. Available from: https://www.ers.usda .gov/data-products/atlas-of-rural-andsmall-town-america/

37. CDC's Social Vulnerability Index (SVI) [Internet]. Atsdr.cdc.gov. 2021 [cited 26 April 2021]. Available from: https://www.atsdr.cdc.gov/placeandhealth/svi/index.html

38. Rue H, Martino S, Chopin N. Approximate Bayesian inference for latent Gaussian models by using integrated nested Laplace approximations. Journal of the royal statistical society: Series b (statistical methodology). 2009 Apr;71(2):319-92.

39. R Core Team. R: A Language and Environment for Statistical Computing [Internet]. Vienna, Austria; 2020. Available from: https://www.R-project.org/.

40. Noor AM, Kinyoki DK, Mundia CW, Kabaria CW, Mutua JW, Alegana VA, Fall IS, Snow RW. The changing risk of Plasmodium falciparum malaria infection in Africa: 2000-10: a spatial and temporal analysis of transmission intensity. The Lancet. 2014 May 17;383(9930):1739-47.

41. Dwyer-Lindgren L, Flaxman AD, Ng M, Hansen GM, Murray CJ, Mokdad AH. Drinking patterns in US counties from 2002 to 2012. American journal of public health. 2015 Jun;105(6):1120-7.

42. Rossen LM, Hedegaard H, Khan D, Warner M. County-level trends in suicide rates in the US, 2005-2015. American journal of preventive medicine. 2018 Jul 1;55(1):72-9.

43. Millett GA, Jones AT, Benkeser D, Baral S, Mercer L, Beyrer C, Honermann B, Lankiewicz E, Mena L, Crowley JS, Sherwood J. Assessing differential impacts of COVID-19 on black communities. Annals of epidemiology. 2020 Jul 1;47:37-44.

44. Ferrari S, Cribari-Neto F. Beta regression for modelling rates and proportions. Journal of applied statistics. 2004 Aug 1;31(7):799-815. 
45. Blangiardo M, Cameletti M, Baio G, Rue H. Spatial and spatio-temporal models with RINLA. Spatial and spatio-temporal epidemiology. 2013 Mar 1;4:33-49.

46. Ugarte MD, Adin A, Goicoa T, Militino AF. On fitting spatio-temporal disease mapping models using approximate Bayesian inference. Statistical methods in medical research. 2014 Dec;23(6):507-30.

47. Besag J, York J, Mollié A. Bayesian image restoration, with two applications in spatial statistics. Annals of the institute of statistical mathematics. 1991 Mar;43(1):1-20.

48. Council of Economic Advisors; Kathryn Zickuhr. 2013. "Who's Not Online and Why," Pew Research Center.

49. Vikki S. Katz and Carmen Gonzalez. 2016. "Toward Meaningful Connectivity: Using Multilevel Communication Research to Reframe Digital Inequality," Journal of Communication 66:2, 236-49.

50. US Department of Health and Human Services, Centers for Disease Control and Prevention, and National Center for Immunization and Respiratory Diseases. A Guide for Community Partners: Increasing COVID-19 Vaccine Uptake Among Members of Racial and Ethnic Minority Communities. April 6, 2021. 
medRxiv preprint doi: https://doi.org/10.1101/2021.05.28.21257946; this version posted May 31, 2021. The copyright holder for this preprint (which was not certified by peer review) is the author/funder, who has granted medRxiv a license to display the preprint in perpetuity.

It is made available under a CC-BY-NC-ND 4.0 International license .

\section{FIGURES \& TABLES}

Figure 1. Cumulative percentage of residents with at least one dose of the COVID-19 vaccine by county $\left(N_{\mathrm{c}}=3138\right)$ and week $\left(N_{\mathrm{t}}=13\right)$, February 21, 2021 through May 16, 2021. Each panel is labelled using a two-letter US state abbreviation. Each point plotted represents data for a county at the end of a given week. Some overplotting may occur; this may lead to an appearance of darker colored points.
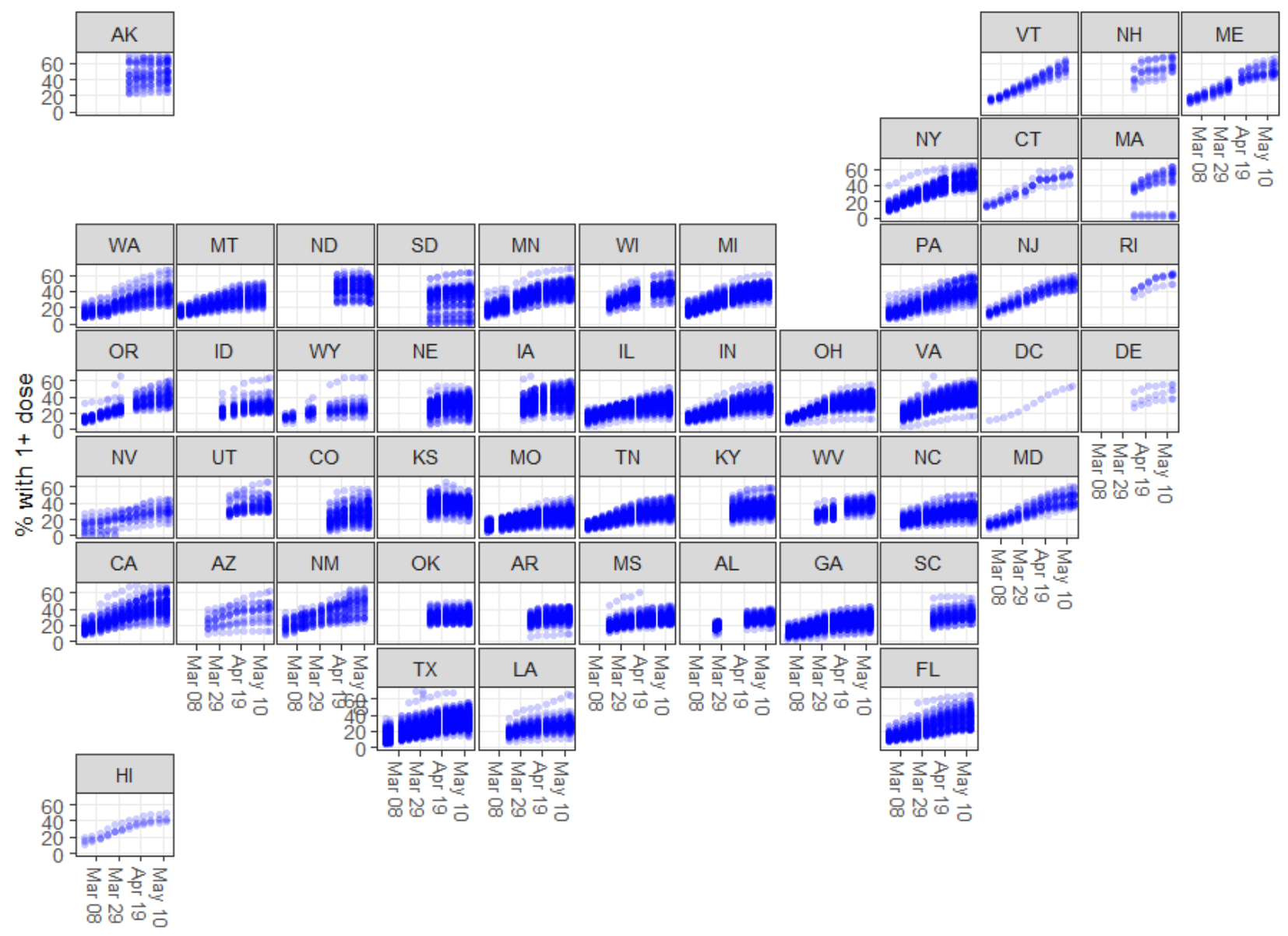

Date 
medRxiv preprint doi: https://doi.org/10.1101/2021.05.28.21257946; this version posted May 31, 2021. The copyright holder for this preprint (which was not certified by peer review) is the author/funder, who has granted medRxiv a license to display the preprint in perpetuity.

It is made available under a CC-BY-NC-ND 4.0 International license .

Figure 2. Estimated coefficients of time-fixed and time-varying US county effects from the selected spatio-temporal Beta regression model with a probit link, sorted by absolute magnitude. All covariates were centered and scaled prior to analysis. Vaccination data cover February 21, 2021 through May 16, 2021.

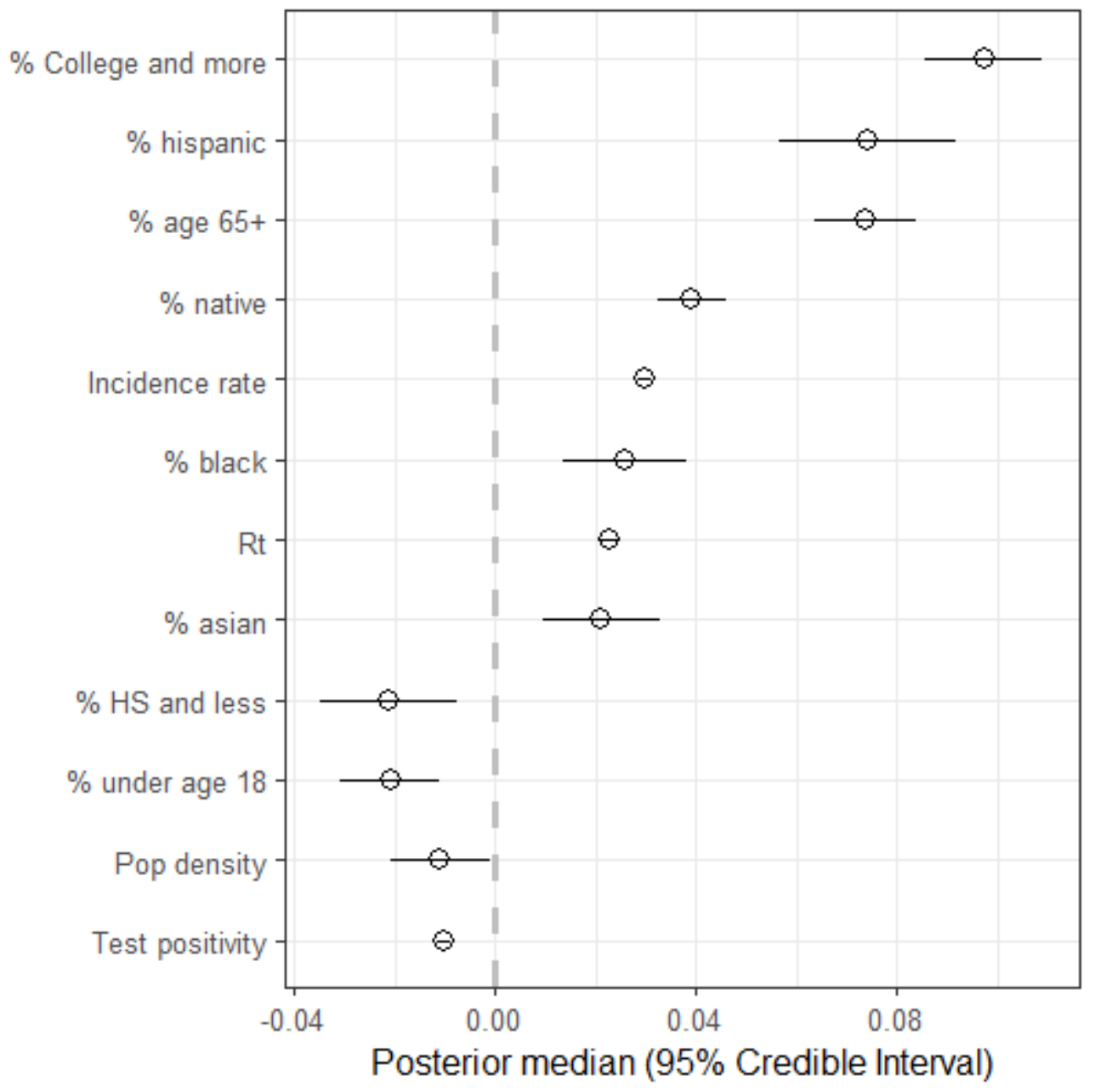


medRxiv preprint doi: https://doi.org/10.1101/2021.05.28.21257946; this version posted May 31, 2021. The copyright holder for this preprint (which was not certified by peer review) is the author/funder, who has granted medRxiv a license to display the preprint in perpetuity.

It is made available under a CC-BY-NC-ND 4.0 International license .

Figure 3. Standardized time-averaged joint (spatial + unstructured) county effects (A) and standardized deviations from the typical trajectory (B). Values $>0$ indicate a county is overperforming its known characteristics; values < 0 indicate a county is under-performing its known characteristics. Diagonal hatch pattern indicates missing data, which occurs in Alaska, Arizona, and South Dakota. Vaccination data cover February 21, 2021 through May 16, 2021.

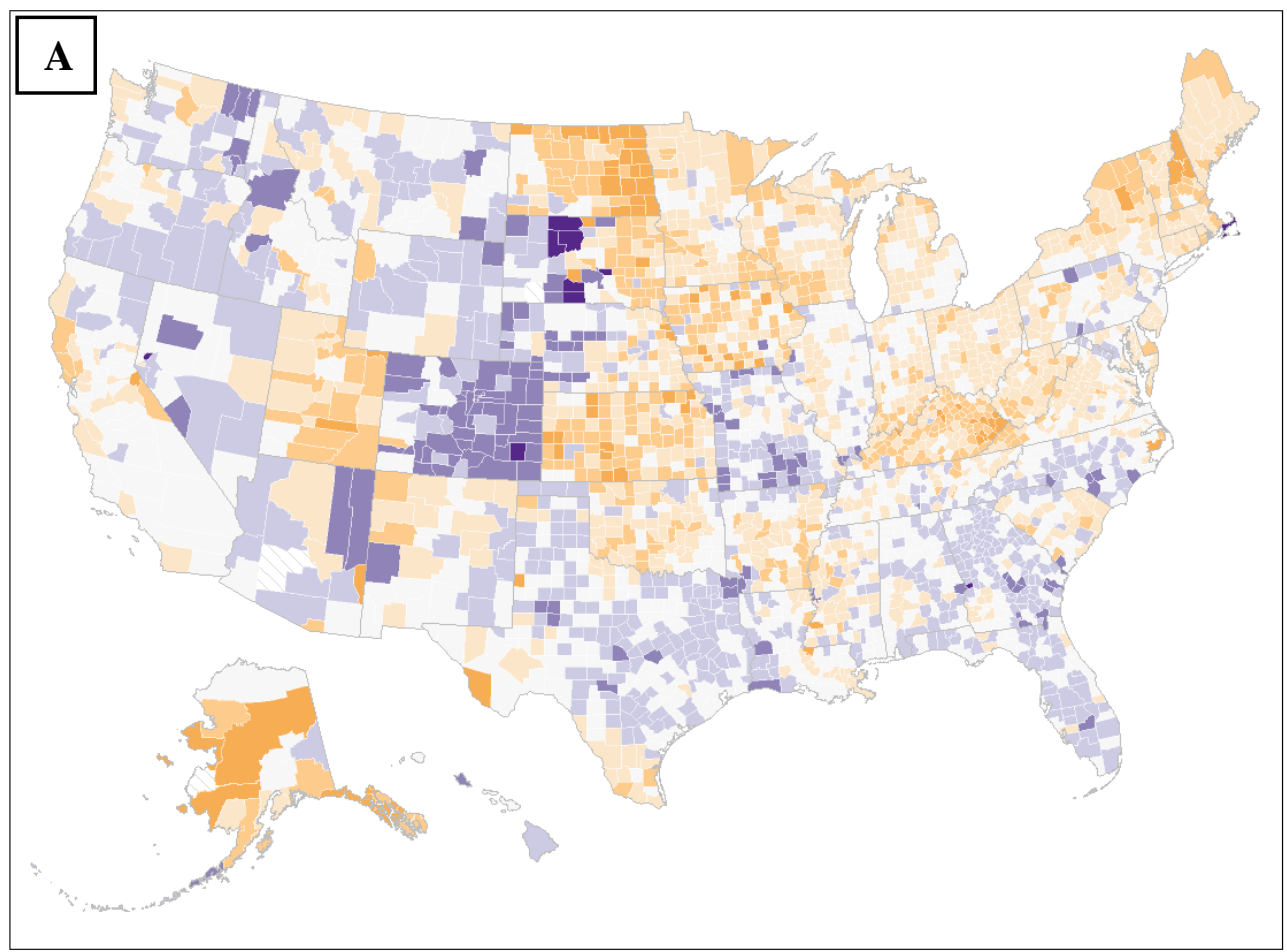

Joint latent

county effect
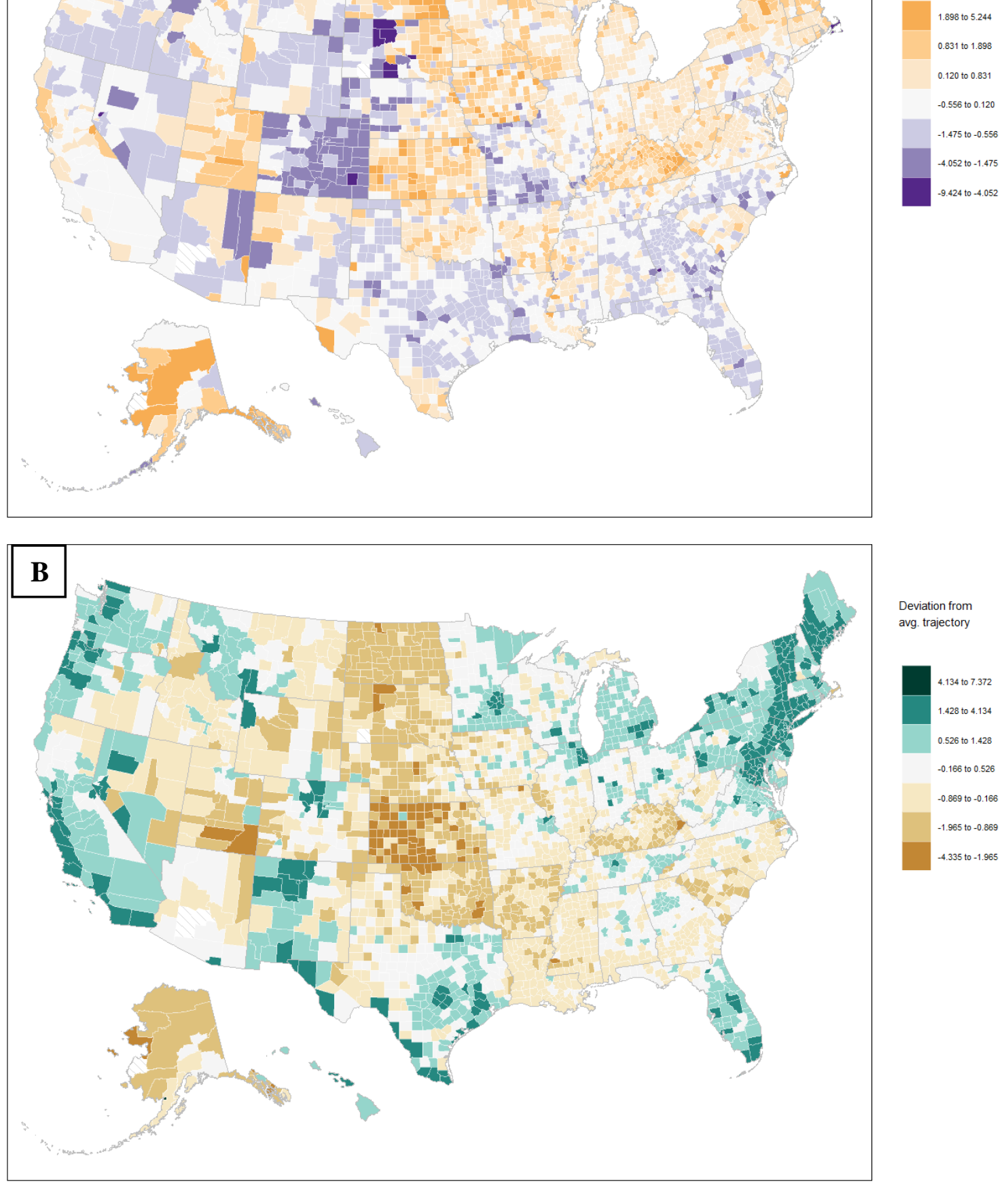

Deviation from

avg. trajectory

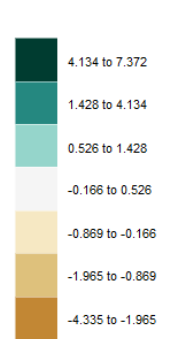


medRxiv preprint doi: https://doi.org/10.1101/2021.05.28.21257946; this version posted May 31, 2021. The copyright holder for this preprint (which was not certified by peer review) is the author/funder, who has granted medRxiv a license to display the preprint in perpetuity.

It is made available under a CC-BY-NC-ND 4.0 International license .

Figure 4. Fitted and forecasted trajectories for representative counties in the top 10\%, top 25\%, median, bottom $25 \%$, and bottom $10 \%$ of estimated trajectories. Vaccination rates for the previous 13 weeks of data as of May 16, 2021 (A) and forecasted vaccination rates (B) are shown. Dashed horizontal line indicates the herd immunity threshold of $70 \%$. Counties in the top $10 \%$ of estimated trajectories are expected to reach herd immunity by the week of Jun 13-19 (I); top $25 \%$ by the week of Jul 25-31 (II); median county by the week of Aug 8-14 (III); bottom $25 \%$ by the week of Dec 26,2021 - Jan 1, 2022 (IV); bottom 10\% not until later in 2022.

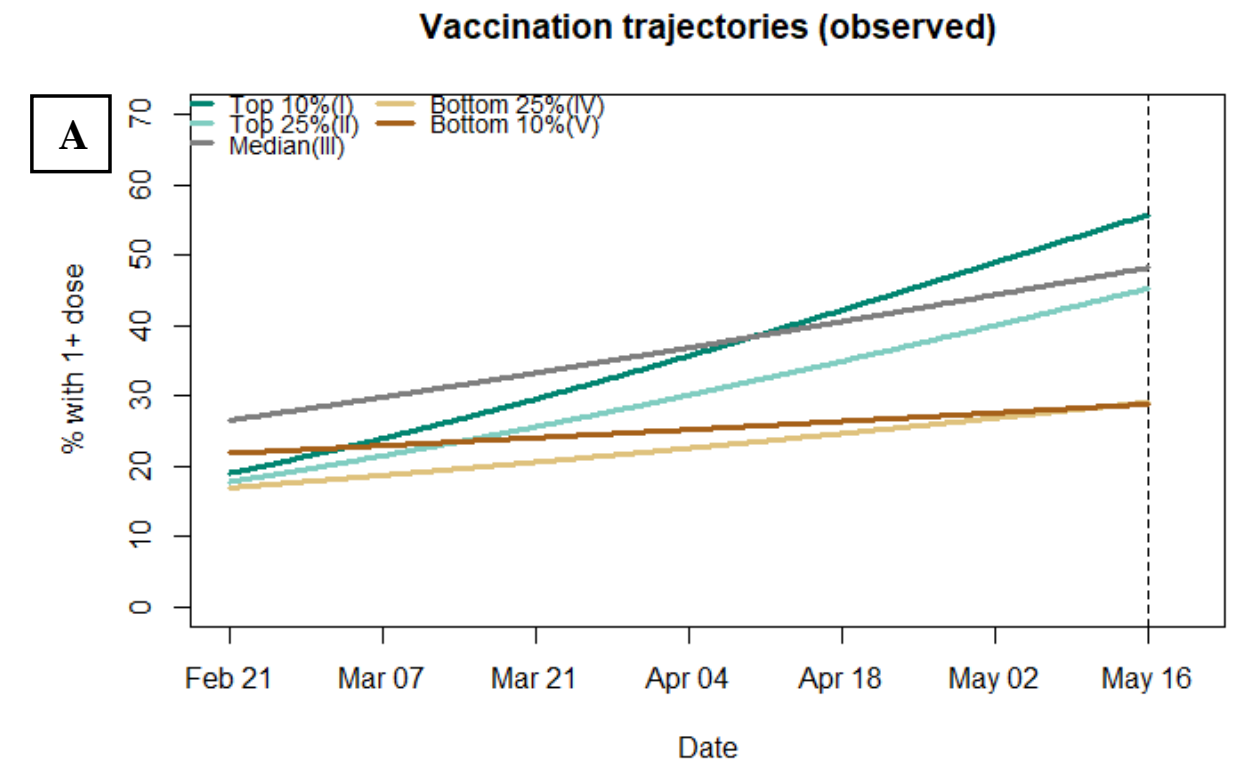

Vaccination trajectories (forecast)

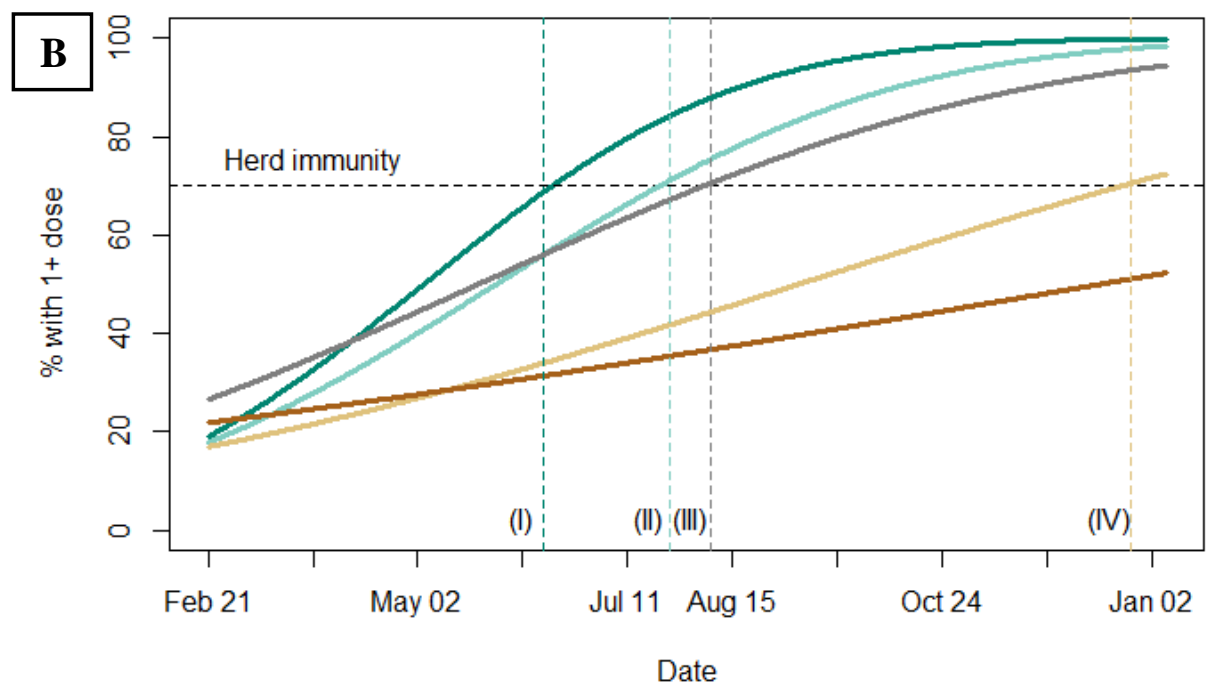


medRxiv preprint doi: https://doi.org/10.1101/2021.05.28.21257946; this version posted May 31, 2021. The copyright holder for this preprint (which was not certified by peer review) is the author/funder, who has granted medRxiv a license to display the preprint in perpetuity.

It is made available under a CC-BY-NC-ND 4.0 International license .

Figure 5. Forecasted percentage of residents with at least one dose by US county for the week ending on July 31 (July 25 - 31) (A) and estimated probability of local herd immunity, i.e. $\operatorname{Pr}$ (prediction > 70\%) (B). Diagonal hatch pattern indicates missing data, which occurs in Alaska, Arizona, and South Dakota. Forecast is based on data from February 21, 2021 through May 16, 2021.

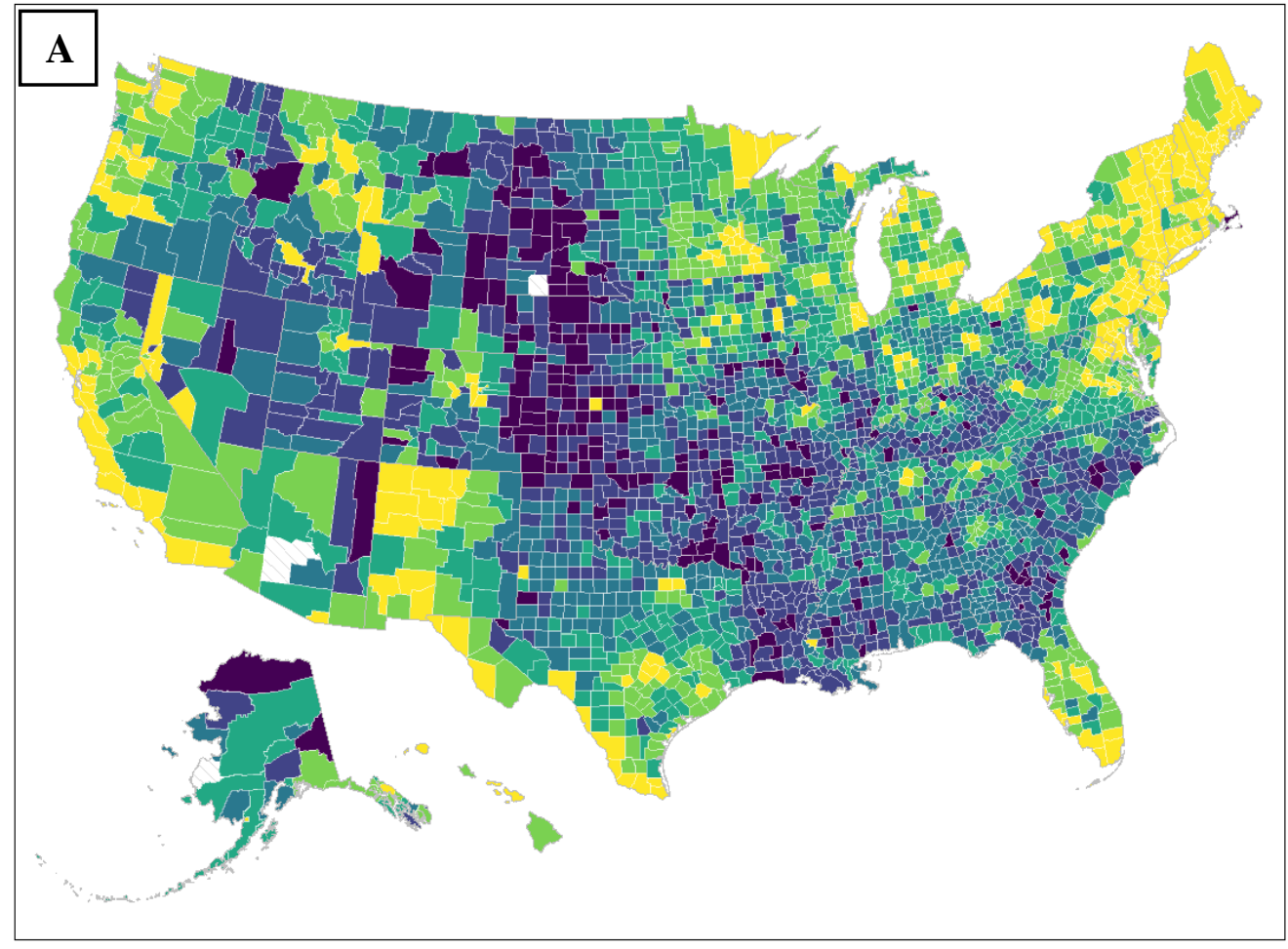

$\%$ with $1+$ dose

by Jul 31, 2021

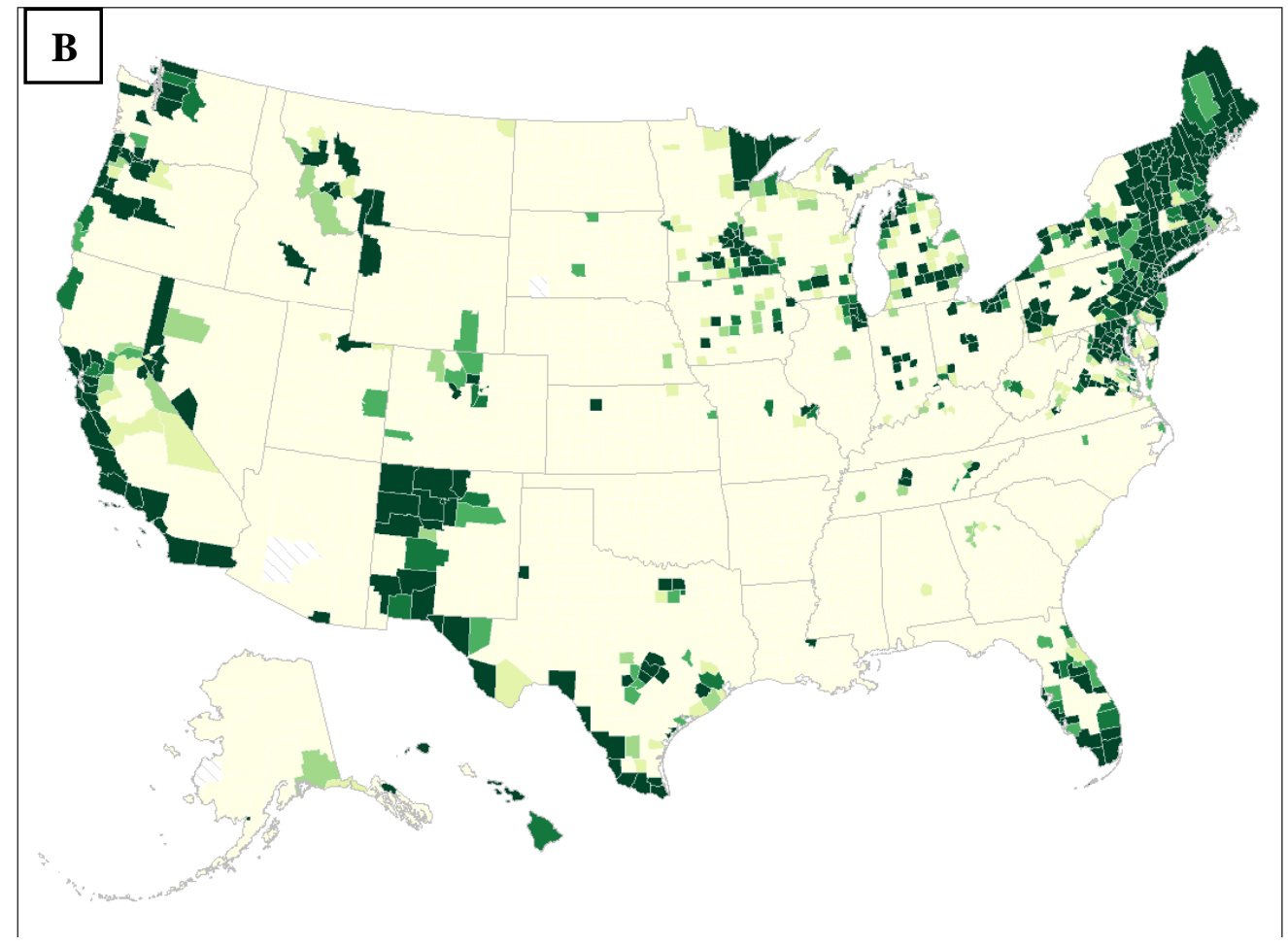

$\operatorname{Pr}$ (Herd immunity)

by Jul 31, 2021 
Table 1. Top 10 counties according to the time-averaged joint (spatial + unstructured) latent effects, as of May 16, 2021. Latent effects measure over- or under- performance under the regression model; counties in this table have overperformed their known characteristics under the model by at least 3SD. County population (2018) and the 2018 CDC Social Vulnerability Index (SVI) percentiles for Themes 1 through 4 are provided for context. SVI percentiles near 0 indicate lowest social vulnerability; percentiles near 1 indicate greatest social vulnerability.

\begin{tabular}{|r|l|l|r|r|r|r|r|}
\hline Rank & State & County name & Population & $\begin{array}{l}\text { Theme 1 } \\
\text { (Socioeco } \\
\text { nomic } \\
\text { Status) }\end{array}$ & $\begin{array}{l}\text { Theme 2 } \\
\text { (Household } \\
\text { composition } \\
\text { \& Disability) }\end{array}$ & $\begin{array}{l}\text { Theme 3 } \\
\text { (Minority } \\
\text { status \& } \\
\text { language) }\end{array}$ & $\begin{array}{l}\text { Theme 4 } \\
\text { (Housing \& } \\
\text { transportation) }\end{array}$ \\
\hline 1 & VA & $\begin{array}{l}\text { Manassas Park } \\
\text { City }\end{array}$ & 16423 & 0.461 & 0.349 & 0.978 & 0.261 \\
\hline 2 & IA & Cass & 13191 & 0.270 & 0.428 & 0.300 & 0.180 \\
\hline 3 & AK & Skagway & 1061 & 0.153 & 0.010 & 0.392 & 0.812 \\
\hline 4 & AK & Yakutat City & 689 & 0.212 & 0.406 & 0.766 & 0.961 \\
\hline 5 & NH & Coos & 32038 & 0.450 & 0.679 & 0.330 & 0.698 \\
\hline 6 & AK & $\begin{array}{l}\text { Petersburg } \\
\text { Borough }\end{array}$ & 3255 & 0.164 & 0.893 & 0.766 & 0.930 \\
\hline 7 & ND & Dickey & 4970 & 0.081 & 0.160 & 0.152 & 0.444 \\
\hline 8 & AK & Sitka City & 8738 & 0.058 & 0.192 & 0.727 & 0.942 \\
\hline 9 & AK & Nome & 9925 & 0.896 & 0.539 & 0.883 & 0.910 \\
\hline 10 & ND & Cavalier & 3824 & 0.048 & 0.119 & 0.251 & 0.037 \\
\hline
\end{tabular}


medRxiv preprint doi: https://doi.org/10.1101/2021.05.28.21257946; this version posted May 31, 2021. The copyright holder for this preprint (which was not certified by peer review) is the author/funder, who has granted medRxiv a license to display the preprint in perpetuity.

It is made available under a CC-BY-NC-ND 4.0 International license.

Table 2. Top 10 counties with most favorable vaccination trajectories, as of May 16, 2021. Counties in this table have the largest positive deviations above the typical vaccination trajectory, by at least 2.8SD. Population (2018) and the 2018 CDC Social Vulnerability Index (SVI) percentiles for Themes 1 through 4 are provided for context. SVI percentiles near 0 indicate lowest social vulnerability; percentiles near 1 indicate greatest social vulnerability.

\begin{tabular}{|c|c|c|c|c|c|c|c|}
\hline Rank & State & County name & Population & $\begin{array}{l}\text { Theme } 1 \\
\text { (Socioeco } \\
\text { nomic } \\
\text { Status) }\end{array}$ & $\begin{array}{l}\text { Theme } 2 \\
\text { (Household } \\
\text { composition \& } \\
\text { Disability) }\end{array}$ & $\begin{array}{l}\text { Theme } 3 \\
\text { (Minority } \\
\text { status \& } \\
\text { language) }\end{array}$ & $\begin{array}{l}\text { Theme } 4 \\
\text { (Housing \& } \\
\text { transportation) }\end{array}$ \\
\hline 1 & VA & $\begin{array}{l}\text { Manassas Park } \\
\text { City }\end{array}$ & 16423 & 0.461 & 0.349 & 0.978 & 0.261 \\
\hline 2 & $\mathrm{AK}$ & $\begin{array}{l}\text { Bristol Bay } \\
\text { Borough }\end{array}$ & 890 & 0.186 & 0.179 & 0.426 & 0.887 \\
\hline 3 & VT & Addison & 36939 & 0.092 & 0.094 & 0.257 & 0.330 \\
\hline 4 & PA & Chester & 517156 & 0.049 & 0.049 & 0.730 & 0.339 \\
\hline 5 & $\mathrm{NV}$ & Douglas & 47828 & 0.124 & 0.266 & 0.667 & 0.145 \\
\hline 6 & VT & Chittenden & 162052 & 0.094 & 0.017 & 0.540 & 0.792 \\
\hline 7 & VT & Lamoille & 25268 & 0.210 & 0.113 & 0.079 & 0.428 \\
\hline 8 & NM & Los Alamos & 18356 & 0.007 & 0.053 & 0.590 & 0.057 \\
\hline 9 & VT & Grand Isle & 6965 & 0.064 & 0.034 & 0.166 & 0.007 \\
\hline 10 & VT & Washington & 58477 & 0.103 & 0.239 & 0.170 & 0.572 \\
\hline
\end{tabular}


管. 泟

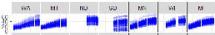

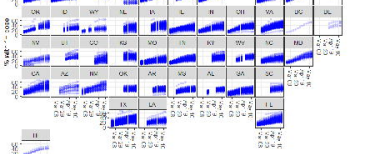

bete

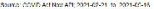




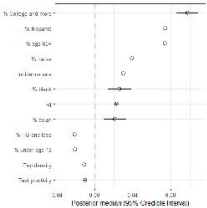



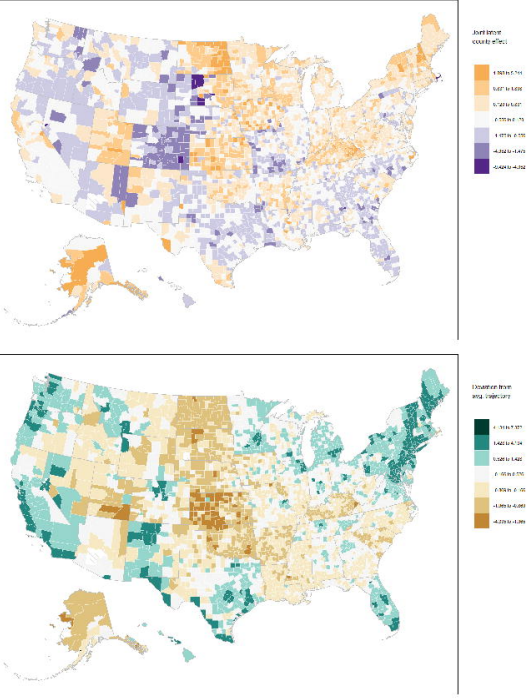


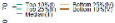

$8-$

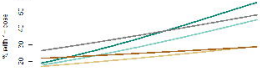

1

6

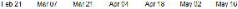

$\Gamma_{i: 2: 2}$

\section{Vaceination trojectorles (forecast)}

$:$

ix

\begin{tabular}{l}
8 \\
7 \\
\hline
\end{tabular}

Ibodinmurily

$\Rightarrow-$

(3)

s-

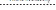




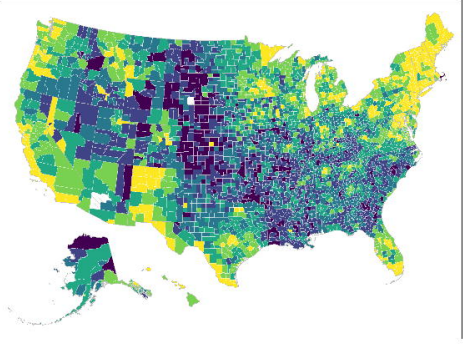

4. anc 1+ ris:

Ly - $121,212 t$
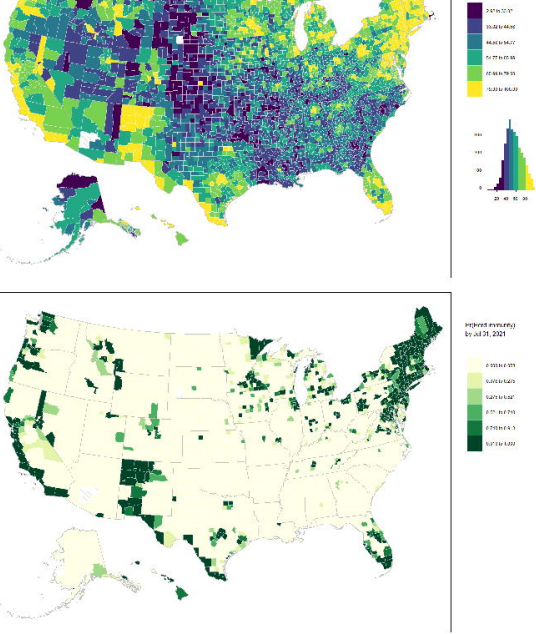